\title{
Pleiotropic Chemodiversity in Extracts and Essential Oil of Melaleuca viminalis and Melaleuca armillaris of Myrtaceae Family
}

\author{
Madhulika Bhagat $^{1 *}$, Monica Sangral ${ }^{1}$, Sudha Pandita ${ }^{1}$, Vironica $^{1}$, Sahil Gupta ${ }^{1}$ and Kushal Bindu ${ }^{2}$ \\ ${ }^{1}$ School of Biotechnology, University of Jammu, J\&K-180006, India; ${ }^{2}$ Indian Institute of Integrative Medicine, J\&K-180001, India .
}

\begin{abstract}
Background and objective: Melaleuca viminalis (syn. Callistemon viminalis, red bottle brush) and Melaleuca armillaris (white Bottle brush) belong to the family Myrtaceae and are reported for their traditional medicinal properties. The objective of this study was to explore and compare the chemical compositions and biological properties of these two species.
\end{abstract}

Methods: Sequential extraction and hydro-distillation methods were employed to extract essential oils for further analysis of chemical composition by gas chromatography-mass spectrometry (GC-MS). The biological potential as antioxidants was investigated for both species by assessing 1,1-diphenyl-2-picrylhydrazyl (commonly known as DPPH) scavenging activity and by use of ferric iron reducing assay. The biological potential as antibacterials was investigated by agar well diffusion assay. The in vitro cytotoxicity analysis was carried out by MTT assay.

Results: GC-MS analysis of the essential oil of Melaleuca viminalis indicated the presence of eucalyptol as the principal chemical constituent, while that of Melaleuca armillaris indicated the presence of methyl eugenol. Comparative studies indicated that Melaleuca viminalis had higher potential for antioxidant and antibacterial activities than Melaleuca armillaris. Also, the essential oil of Melaleuca viminalis exhibited in vitro cytotoxicity against the cancer cell lines of A549 (lung; IC ${ }_{50} 24.12 \mu \mathrm{g} / \mathrm{mL}$ ), HCT-116 (colon; IC ${ }_{50} 21.5 \mu \mathrm{g} / \mathrm{mL}$ ) and T47D (breast; IC ${ }_{50} 21.78$ $\mu \mathrm{g} / \mathrm{mL}$ ), in comparison to Melaleuca armillaris for which cytotoxicity was only observed against theA549 $\left(\mathrm{IC}_{50}\right.$ $10.2 \mu \mathrm{g} / \mathrm{mL}$ ) lung cancer cell line.

Conclusions: The present findings suggest that essential oil of Melaleuca viminalis (leaves) hold potential for future application in various medical procedures. However, the presence of methyl eugenol in Melaleuca armillaris raises concern of its being acarcinogenic compound, so further detailed toxicological studies are required to validate its therapeutic potential.

Introduction

Myrtaceae (121 genera, 3,800-5,800 spp.) is one of the largest fami-

Keywords: Antibacterial; Antioxidant; Cytotoxicity; Essential oil; Eucalyptol; Melaleuca armillaris; Melaleuca viminalis; Methyl eugenol; Myrtaceae.

Abbreviations: DPPH, 1,1-diphenyl-2-picrylhydrazyl; ELISA, enzyme-linked immunosorbent assay; $\mathrm{IC}_{50}$, concentration of drug inhibiting cell growth by $50 \%$; MTT, 3-(4,5-dimethylthiazol-2-yl)-2,5-diphenyltetrazolium bromide.

Received: December 15, 2017; Revised: September 12, 2017; Accepted: November 13, 2017

*Correspondence to: Madhulika Bhagat, School of Biotechnology, University of Jammu, J\&K-180006, India. E-mail: madhulikasbt@gmail.com

How to cite this article: Bhagat M, Sangral M, Pandita S, Vironica, Gupta S, Bindu K. Pleiotropic Chemodiversity in Extracts and Essential Oil of Melaleuca viminalis and Melaleuca armillaris of Myrtaceae Family. J Explor Res Pharmacol 2017;2(4):113-120. doi: 10.14218/JERP.2016.00036. lies of tropical forest plants, comprises of aromatic trees or shrubs. Economically important essential oils have been reported from several species of the Melaleuca genus and are known to possess diverse bioactivity (viz., antidiarrheal, antimicrobial, antioxidant, antirheumatic, anti-inflammatory anticough, antibronchitis, insecticidal, antiphylococcal, nematicidal, larvicidal, pupicidal and antithrombotic, etc.). ${ }^{1,2}$

Traditionally, M. viminalis leaves have been used as tea substitute, having refreshing flavor and fragrance; they have also been used as treatment against various diseases, including gastroenteritis, diarrhea and skin infections. ${ }^{3,4}$ Apart from medical applications, it has also been reported to act as environmental bioindicators and to have antiquorum sensing activities. ${ }^{5-7}$ Another species, $M$. armillaris, is most widely cultivated around the world as an ornamental plant, but there is scarce literature regarding investigations into its biological activities..$^{8-11}$ However, studies of the chemical composition of its oil have shown predominance of ses- 
quiterpenes; unfortunately, variation has been frequently observed during the quantitative analysis, which depends majorly upon the taxonomic identity and population being studied. ${ }^{12-14}$

As continuation to our earlier studies on essential oils isolated from plants of the Northwestern Himalayan region, herein we describe our most recent studies on the chemical composition and in vitro biological properties of the essential oils from Melaleuca viminalis (red bottle brush) and Melaleuca armillaris (white bottle brush).

\section{Methods}

\section{Collection of plants and extraction}

The aerial parts (leaves) of both the plant species were collected from the botanical garden of the University of Jammu, Jammu and Kashmir (India) and were identified by the taxonomist of the University. Different extracts were prepared with different solvents based on polarity. For chloroform extract, powdered plant material $(100 \mathrm{~g})$ was soaked in chloroform for 24 hand then filtered. The resultant filtrate was further evaporated using a rotary evaporator, and the extract obtained was lyophilized and stored at $4{ }^{\circ} \mathrm{C}$. Similarly, the residue was then sequentially processed with ethyl acetate, acetone, methanol and water.

\section{Extraction of essential oil}

Two hundred grams of fresh leaves of each Melaleuca species were hydro-distillated with a Clevenger-type apparatus for $3 \mathrm{~h}^{15}$ The yield of essential oil from both the species was calculated based on the fresh weight. Samples were stored at $4{ }^{\circ} \mathrm{C}$.

\section{Chemical screening}

\section{Qualitative screening of extracts of leaves of $M$. viminalis and M. armillaris}

To test the presence or absence of phytochemical constituents (viz., tannins, saponins, terpenoids, coumarins, quinines, anthraquinones, cardiac glycosides, etc.), extracts were qualitatively screened. ${ }^{16}$

\section{Saponins}

A $1 \mathrm{mg} / \mathrm{mL}$ stock solution of the extracts in methanol and distilled water were vortexed, after which a few drops of olive oil/refined oil was added. Persistence of foam indicated the presence of saponins.

\section{Tannins}

A $1 \mathrm{mg} / \mathrm{mL}$ stock solution of the extract was mixed with methanol and stirred with 5\% ferric chloride solution. Appearance of a black precipitate indicated the presence of tannins.

\section{Terpenoids}

A $1 \mathrm{mg} / \mathrm{mL}$ stock solution of the extract was mixed with methanol, chloroform $(1 \mathrm{~mL})$ and concentrated $\mathrm{H}_{2} \mathrm{SO}_{4}(1.5 \mathrm{~mL})$. Appearance of reddish-brown coloration at the interface indicated the presence of terpenoids.

\section{Coumarins}

A $1 \mathrm{mg} / \mathrm{mL}$ stock solution of the extract was mixed with methanol, $10 \% \mathrm{NaOH}(1 \mathrm{~mL})$ and chloroform $(1 \mathrm{~mL})$. Presence of yellowish color indicated the presence of coumarins.

\section{Quinones}

A $1 \mathrm{mg} / \mathrm{mL}$ stock solution of the extract was mixed with methanol and $\mathrm{NaOH}(1 \mathrm{~mL})$. The disappearance of bluish green or red color indicates the presence of quinines.

\section{Anthraquinones}

A $1 \mathrm{mg} / \mathrm{mL}$ stock solution of the extract was mixed with methanol and chloroform $(2.5 \mathrm{~mL})$, further vortexed $(5 \mathrm{~m})$, filtered and an equal volume of $10 \%$ ammonia $(3.5 \mathrm{~mL})$ was added. The appearance of pink, violet or red coloration indicated the presence of anthraquinones.

\section{Cardiac glycosides}

A $1 \mathrm{mg} / \mathrm{mL}$ stock solution of extract was mixed with methanol, glacial acetic acid ( $2 \mathrm{~mL}$ ), ferric chloride solution (one drop) and $1 \mathrm{~mL}$ of concentrated $\mathrm{H}_{2} \mathrm{SO}_{4}$. Presence of a brown colored ring at the interface indicated the presence of deoxysugar, characteristic of carotenoids.

\section{Total phenolic content}

Total phenolic content was determined according to the Folin-Ciocalteau method. ${ }^{17} \mathrm{~A} 0.5 \mathrm{~mL}$ aliquot of the $1 \mathrm{mg} / \mathrm{mL}$ extractstock solution was mixed with $0.5 \mathrm{~mL}$ of $1 \mathrm{~N}$ Folin-Ciocalteau reagent. After $5 \mathrm{~m}, 1 \mathrm{~mL}$ of $20 \% \mathrm{Na}_{2} \mathrm{CO}_{3}$ was added. After $10 \mathrm{~m}$ of incubation at room temperature, the absorbance was measured at $750 \mathrm{~nm}$ using a spectrophotometer. The concentration of phenolic compounds was calculated according to the following equation obtained from the standard gallic acid: Absorbance $=0.0364$ gallic acid $(\mu \mathrm{g})+0.009$.

\section{Total flavonoid content}

Total flavonoid content was determined by a colorimetric method. ${ }^{17,18} \mathrm{~A} 0.5 \mathrm{~mL}$ aliquot of the $1 \mathrm{mg} / \mathrm{mL}$ extract stock solution was mixed with $150 \mu \mathrm{L}$ of a $5 \% \mathrm{NaNO}_{2}$ solution. After $5 \mathrm{~m}, 300 \mu \mathrm{L}$ of $10 \% \mathrm{AlCl}_{3} \cdot \mathrm{H}_{2} \mathrm{O}$ solution, $300 \mu \mathrm{L}$ of $1 \mathrm{M} \mathrm{NaOH}$ and $550 \mu \mathrm{L}$ of distilled water were added. The solution was mixed well and the absorbance was observed at $510 \mathrm{~nm}$ using a UV-VIS spectrophotometer. The concentration of flavonoid compounds was calculated according to the equation obtained from the standard quercetin graph: Absorbance $=0.001$ quercetin $(\mu \mathrm{g})+0.032$.

\section{Chemical analysis by gas chromatography-mass spectrometry} (GC-MS)

Analysis of the oil was carried out at the CSIR-Indian Institute of 
Integrative Medicine(India) using the Varian GC-MS 4000 (USA) system equipped with a Varian CP-SIL 8CB column $(30 \mathrm{~m} \times 0.32$ $\mathrm{mm}$ i.d., $1 \mu \mathrm{m}$ film thickness). The injector temperature was 230 ${ }^{\circ} \mathrm{C}$. The oven temperature program used consisted ofholding at 60 ${ }^{\circ} \mathrm{C}$ for $5 \mathrm{~m}$, heating to $250{ }^{\circ} \mathrm{C}$ at $3{ }^{\circ} \mathrm{C} /$ mand keeping the temperature constant at $250^{\circ} \mathrm{C}$ for $10 \mathrm{~m}$. Helium was used as a carrier gas at a constant flow of $1.0 \mathrm{~mL} / \mathrm{m}$, and an injection volume of 0.20 $\mu \mathrm{L}$ was employed. The MS scan parameters included electron impact ionization voltage of $70 \mathrm{eV}$, and a mass range of $40-500 \mathrm{~m} / \mathrm{z}$. The identification of components of the essential oil was based on comparison of their mass spectra with those of the NIST05 (version 2.0) library.

\section{Biological activities}

\section{1,1-diphenyl-2-picrylhydrazyl (DPPH) radical scavenging assay}

The free radical scavenging activity was determined according to the method of Blois (1958) with some modifications. ${ }^{19}$ Aliquots of $50 \mu \mathrm{g} / \mathrm{mL}, 100 \mu \mathrm{g} / \mathrm{mL}, 150 \mu \mathrm{g} / \mathrm{mL}, 200 \mu \mathrm{g} / \mathrm{mL}$ and $250 \mu \mathrm{g} /$ $\mathrm{mL}$ of the test sample were mixed with $1 \mathrm{~mL}$ of $0.5 \mathrm{mM}$ solution of DPPH in methanol. To these, $2 \mathrm{~mL}$ of $0.1 \mathrm{M}$ sodium acetate buffer ( $\mathrm{pH}$ 5.5) was added respectively. The mixtures were then allowed to stand at room temperature in the dark for $30 \mathrm{~m}$. The absorbance was measured at $517 \mathrm{~nm}$ using a double beam UV-VIS spectrophotometer. The radical scavenging activity was calculated as a percentage of DPPH radical discoloration from dark purple to yellow, using the equation: \% radical scavenging activity $=\left[\left(\mathrm{A}_{0}-=\right.\right.$ $\left.\left.{ }_{\mathrm{s}}\right) / \mathrm{A}_{0}\right] \times 100$, where $\mathrm{A}_{0}$ was the absorbance of the control and $A_{\mathrm{s}}$ was the absorbance of the test compound.

\section{Ferric ion reducing antioxidant power (FRAP) assay}

FRAP activity was measured according to the method of Benzie and Strain (1996). ${ }^{20}$ Acetate buffer (300 mM, pH 3.6), $10 \mathrm{mM}$ TPTZ (2,4,6-tripyridyl-s-triazine in $\mathrm{HCl})$ and $\mathrm{FeCl}_{3} \cdot 6 \mathrm{H}_{2} \mathrm{O}(20$ $\mathrm{mM}$ ) were prepared and mixed in the ratio of 10:1:1. The test sample $(100 \mu \mathrm{L})$ was mixed with $3 \mathrm{~mL}$ of working FRAP reagent, and absorbance was measured at $593 \mathrm{~nm}$ after vortexing. $\mathrm{FeSO}_{4} \cdot 7 \mathrm{H}_{2} \mathrm{O}$ $(100-2,000 \mu \mathrm{M})$ were prepared in methanol and used as the standard for the calibration curve of known $\mathrm{Fe}^{2+}$ concentration. The parameter equivalent concentration was defined as the concentration of antioxidant having a ferric-TPTZ reducing ability equivalent to that of $1 \mathrm{mM} \mathrm{FeSO}_{4} \cdot 7 \mathrm{H}_{2} \mathrm{O}$.

\section{Antibacterial screening}

The antibacterial activities of the crude extracts of $M$. viminalisand M. armillariswere determined by the agar well diffusion method. ${ }^{21}$ The bacterial isolates were first grown by streaking on a nutrient agar plate and incubating for $24 \mathrm{~h}$ at $37^{\circ} \mathrm{C}$ before use. Cell suspension was prepared by dissolving a loop full of culture from the culture plate in $200 \mu \mathrm{L}$ of autoclaved nutrient broth. Then, a 100 $\mu \mathrm{L}$ aliquot of the respective cell suspensions was spread on nutrient agar plates using a sterile glass spreader and allowed to absorb in the agar for $30 \mathrm{~m}$. Furthermore, four wells $(6 \mathrm{~mm})$ were bored in each agar plate and a $20 \mu \mathrm{L}$ solution of $1 \mu \mathrm{g} / \mu \mathrm{L}$ extracts/essential oil was added. Plates were incubated at $37^{\circ} \mathrm{C}$ for $18 \mathrm{~h}$ and then observed for zones of inhibition. The effect was compared with that of the positive reference ampicillin to determine the sensitivity of bacterial growth. Each sample was applied in duplicate for the determination of antibacterial activity.

\section{In vitro cytotoxicity assay against human cancer cell lines}

In vitro cytotoxicity against human cancer cell lines was measured by the tetrazolium-based colorimetric assay which measures the reduction of the tetrazolium salt 3-[4,5-dimethylthiazol-2-yl]-2,5diphenyltetrazolium bromide (MTT) into a blue formazan product, mainly by the activity of the mitochondrial enzymes, cytochrome oxidase and succinate dehydrogenase. ${ }^{22}$ Typically, $100 \mu \mathrm{L}$ of a cell suspension was plated at a density of approximately $2 \times 10^{4}$ cells per well in a 96-well plate and were subsequently incubated at 37 ${ }^{\circ} \mathrm{C}$ in a $5 \% \mathrm{CO}_{2}$ humidified incubator for $24 \mathrm{~h}$. Different concentrations of the essential oil and extracts were added to each group (in triplicate wells) and were incubated for $24 \mathrm{~h}$, followed by the addition of $10 \mu \mathrm{L}(5 \mathrm{mg} / \mathrm{mL})$ MTT dye solution to each well and incubation for $4 \mathrm{~h}$ at $37^{\circ} \mathrm{C}$. After removal of the MTT dye solution, the cells were treated with $100 \mu \mathrm{L}$ DMSO and absorbance at $490 \mathrm{~nm}$ was quantified using an enzyme-linked immunoassay (ELISA) plate reader. The cytotoxicity was calculated after comparing with the control (treated with $0.1 \%$ DMSO). Cytotoxicity was expressed as the concentration of drug inhibiting cell growth by $50 \%\left(\mathrm{IC}_{50}\right)$. All tests and analysis were run in $100 \mu \mathrm{L}$ DMSO and the absorbance at $490 \mathrm{~nm}$ was quantified by using ELISA reader. The cytotoxicity was calculated after comparing with the control (treated with $0.1 \%$ DMSO). Cytotoxicity was expressed as the concentration of drug inhibiting cell growth by $50 \%\left(\mathrm{IC}_{50}\right)$. All tests and analyses were run in triplicate.

\section{Results}

\section{Percentage yield}

$M$. viminalis showed the highest yield in water extract (3.12\%), followed by methanol extract $(2.50 \%)$, chloroform extract $(2.15 \%)$, ethyl acetate extract $(1.90 \%)$ and acetone extract $(1.95 \%)$; whereas, $M$. viminalis essential oil yield was $0.39 \%$. In the case of $M$. armillaris, the highest yield was found in acetone extract $(2.42 \%)$, followed by water extract $(2.07 \%)$, methanol extract $(1.33 \%)$ and ethyl acetate extract $(1.11 \%)$; whereas the essential oil yield was $1.14 \%$.

\section{Qualitative phytochemical assays of extracts}

The qualitative phytochemical analysis of $M$. viminalis and $M$. armillaris (leaves) are depicted in Table 1 . The presence of terpenoids was found to be highest in $M$. viminalis methanolic extract; whereas, the presence of tannins was observed in the ethyl acetate and methanol extracts. Anthraquinones, coumarins, saponins and cardiac glycosides were moderately present in the chloroform, methanol and acetone extracts, while quinones were absent in $M$. viminalis. $M$. armillaris showed moderate presence of coumarins in acetone and methanol extracts; quinones, cardiac glycosides, tannins and anthraquinones were absent in all the extracts of $M$. armillaris.

\section{Total phenolic and flavonoid content}

A high content of phenolics was observed in M. viminalis methanol 
Table 1. Phytochemical profiles of extracts of $M$. viminalis (M.v) and M. armillaris (M.a)

\begin{tabular}{|c|c|c|c|c|c|c|c|c|c|c|c|}
\hline \multirow{3}{*}{ No. } & \multirow{3}{*}{ Phytochemical } & \multicolumn{10}{|c|}{ Extracts } \\
\hline & & \multicolumn{2}{|c|}{ Chloroform } & \multicolumn{2}{|c|}{ Ethyl acetate } & \multicolumn{2}{|c|}{ Acetone } & \multicolumn{2}{|c|}{ Methanol } & \multicolumn{2}{|c|}{ Water } \\
\hline & & M.v & M.a & M.v & M.a & M.v & M.a & M.v & M.a & M.v & M.a \\
\hline 1 & Tannins & - & - & +++ & - & - & - & +++ & - & - & - \\
\hline 2 & Coumerins & ++ & + & - & - & ++ & ++ & + & ++ & - & - \\
\hline 3 & Terpenoids & + & + & - & ++ & ++ & ++ & + & +++ & - & - \\
\hline 4 & Cardiac glycosides & - & - & - & - & ++ & - & +++ & - & - & - \\
\hline 5 & Saponins & - & - & - & - & - & + & - & + & - & - \\
\hline 6 & Quinones & - & - & - & - & - & - & - & - & - & - \\
\hline 7 & Anthraquinones & - & - & + & - & - & - & + & - & - & - \\
\hline
\end{tabular}

+++, strongly present; ++, moderately present; +, present; -, absent.

extract $(16 \pm 0.11 \mathrm{mg} / \mathrm{g}$ GAE), followed by acetone extract $(14 \pm$ $0.010 \mathrm{mg} / \mathrm{g} \mathrm{GAE})$, ethyl acetate extract $(12 \pm 0.009 \mathrm{mg} / \mathrm{g} \mathrm{GAE})$ and chloroform extract $(10 \pm 0.076 \mathrm{mg} / \mathrm{g}$ GAE); whereas, M. armillaris showed the highest phenolic content in methanolic extract (14 $\pm 0.010 \mathrm{mg} / \mathrm{g}$ GAE$)$, followed by acetone extract $(8 \pm 0.005 \mathrm{mg} / \mathrm{g}$ GAE), ethyl acetate extract ( $6 \pm 0.005 \mathrm{mg} / \mathrm{g} \mathrm{GAE})$, chloroform extract $(4 \pm 0.003 \mathrm{mg} / \mathrm{g} \mathrm{GAE})$ and water extract $(2 \pm 0.001 \mathrm{mg} / \mathrm{g} \mathrm{GAE})$.

Similarly, high-content flavonoids in $M$. viminaliswas observed in methanolic extract $(10 \pm 0.072 \mathrm{mg} / \mathrm{g} \mathrm{QE})$, followed by acetone extract $(6 \pm 0.067 \mathrm{mg} / \mathrm{g}$ QE), ethyl acetate extract $(5 \pm 0.064 \mathrm{mg} / \mathrm{g}$ $\mathrm{QE})$, water extract $(4 \pm 0.066 \mathrm{mg} / \mathrm{g} \mathrm{QE})$ and chloroform extract (3 $\pm 0.051 \mathrm{mg} / \mathrm{g} \mathrm{QE})$; whereas, the M. armillaris highest flavonoid content was present in methanolic extract $(11 \pm 0.072 \mathrm{mg} / \mathrm{g} \mathrm{QE})$, followed by acetone extract $(10 \pm 0.007 \mathrm{mg} / \mathrm{g} \mathrm{QE})$, ethyl acetate extract $(7 \pm 0.060 \mathrm{mg} / \mathrm{g} \mathrm{QE})$, chloroform extract $(5 \pm 0.062 \mathrm{mg} / \mathrm{g}$ $\mathrm{QE})$ and water extract $(2 \pm 0.056 \mathrm{mg} / \mathrm{g} \mathrm{QE})$.

\section{GC-MS findingsof the essential oils}

The chemical composition of the essential oil of $M$. viminalis revealed the presence of six major compounds (Fig. 1A). Among all the other compounds, eucalyptol $(74.613 \%)$ was present in the highest amount, followed by alpha-pinene $(8.889 \%)$, alpha-terpineo $(5.573 \%)$, para cymene $(5.272 \%)$, limonene $(4.290 \%)$ and 4-terpineno (1.363\%). The chemical composition of M. armillaris revealed the presence of two major compounds, with the highest content being for methyl eugenol $(94.283 \%)$ followed by methyl cinnamate $(5.717 \%)$ (Fig. 1B).

\section{Biological activities}

\section{DPPH radical scavenging assay findings}

The radical scavenging capacities of extracts and oils of $M$. viminalis and M. armillaris were tested by using the free radical DPPH assay. Both essential oils showed antioxidant properties, with the methanolic extract of $M$. viminalis showing high antioxidant activity followed by the acetone and chloroform extracts; whereas, the methanolic extract of M. armillaris was found to be a good antioxidant. Among the essential oils, that of $M$. viminalis possessed high antioxidant activity compared with that of $M$. armillaris. The $\mathrm{IC}_{50} \mu \mathrm{g} / \mathrm{mL}$ scavenging activity of extracts and essential oils are depicted in Figure 2.

\section{FRAP assay findings}

High FRAP was observed in both the plants (i.e. M. viminalis and M. armillaris). Among all the extracts, the chloroform extracts of both plants showed good ferric reducing power potential (Fig. 3).

\section{Antibacterial activities}

The essential oils and extracts of both the plants showed varied activities against the tested bacteria. Both the extracts and oils of $M$. viminalis and $M$. armillaris were found to be effective against

\section{A Percentages of chemical compositions of M. viminalis essential oil (leaves)}

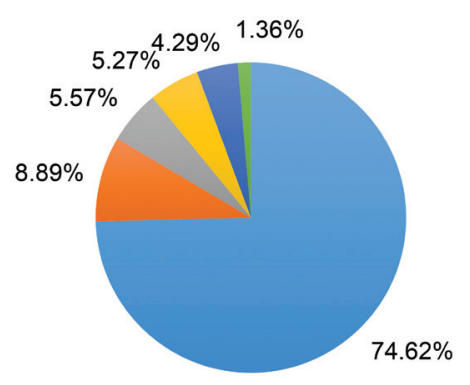

\author{
Eucalyptol \\ - Alpha-pinene \\ Alpha-terpineol \\ - Para Cymene \\ - Limonene \\ 4-Terpinenol
}

\section{B Percentages of chemical compositions of M. armillaris essential oil (leaves)}

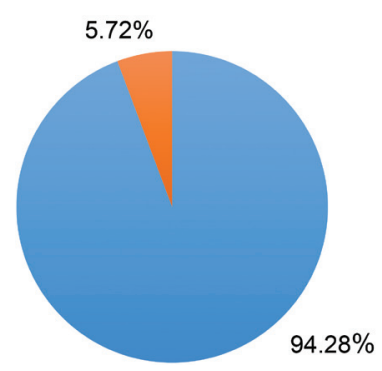

- Methyl eugenol
- Methyl cinnamate

Fig. 1. Percentages of chemical compositions of $M$. viminalis and $M$. armillaris essential oil (leaves). 


\section{DPPH potential of extract and essential oils of $M$. viminalis and $M$. armillaris}

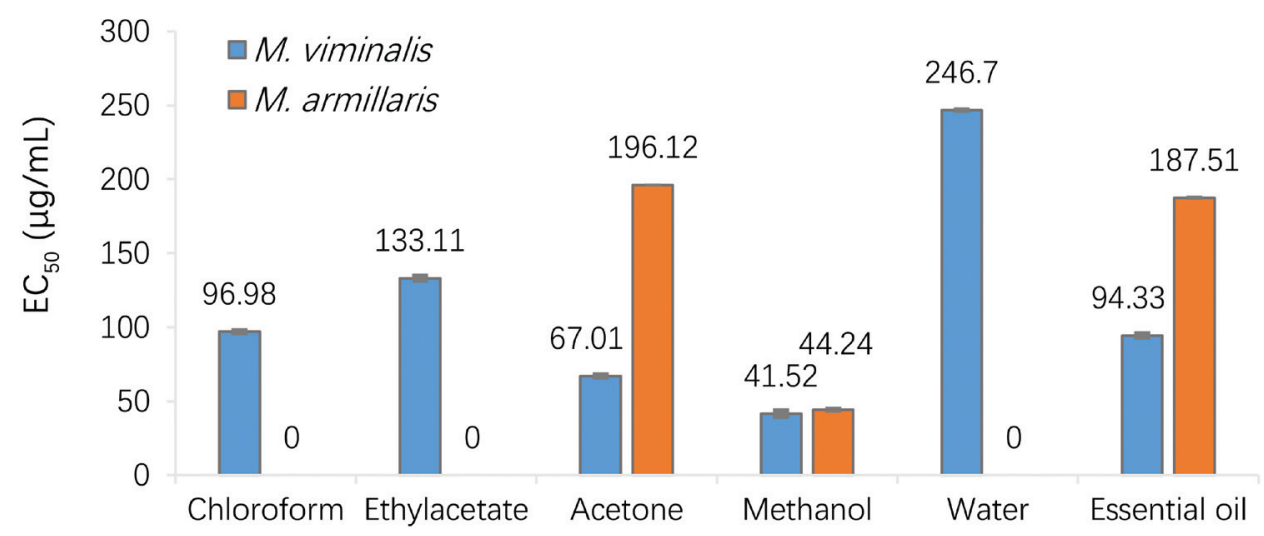

Fig. 2. Free radical scavenging (DPPH) potential of extracts and essential oils of $M$. viminalisand $M$. armillaris.

all the microbes tested. The highest antimicrobial activity was observed against Gram-positive bacteria, in comparison to Gramnegative bacteria. In the case of $M$. viminalis, the essential oil showed the largest zone of inhibition $(23 \mathrm{~mm})$ against $B$. subtilis, followed by the chloroform extract $(23 \mathrm{~mm})$ against $S$. aureus. Whereas for $M$. armillaris, the essential oil showed the largest zone of inhibition against $S$. aureus $(19 \pm 1.22 \mathrm{~mm})$, followed by the chloroform extract against $K$. pneumoniae $(11 \pm 1.22 \mathrm{~mm})$, and the methanol extract showed activity against $B$. subtilis $(10 \pm 1.5$ $\mathrm{mm}$ ) (Tables 2 and 3).

\section{In vitro cytotoxicity against human cancer cell lines}

M. viminalis and M. armillaris essential oils demonstrated significant in vitro cytotoxic activity against the cancer cell lines for lung (A549), colon (HCT-116) and breast (T47 d). M. viminalis essen- tial oil was found to be more effective against the colon HCT-116 $\left(\mathrm{IC}_{50} 21.5 \mu \mathrm{g} / \mathrm{mL}\right)$ and breast T47D, $\left(\mathrm{IC}_{50} 21.78 \mu \mathrm{g} / \mathrm{mL}\right)$ cancer cell lines, whereas $M$. armillaris essential oil was found to be effective against lung A549 ( $\mathrm{IC}_{50} 10.2 \mu \mathrm{g} / \mathrm{mL}$ ) only (Fig. 4).

Discussion

Nature is a rich source of biological and chemical diversity. The unique and complex structures of natural products cannot be obtained easily by chemical synthesis. ${ }^{23}$ Plant essential oils and extracts have been used for many thousands of years in food preservation and as pharmaceuticals, alternative medicines and natural therapies. ${ }^{24-26}$ Some of them constitute effective alternatives or complements to synthetic compounds of the chemical industry, without exerting the secondary effects of the latter. ${ }^{27}$

As reported earlier, essential oils of the Myrtaceae family are

\section{FRAP of extract and essential oils of $M$. viminalis and $M$. armillaris}

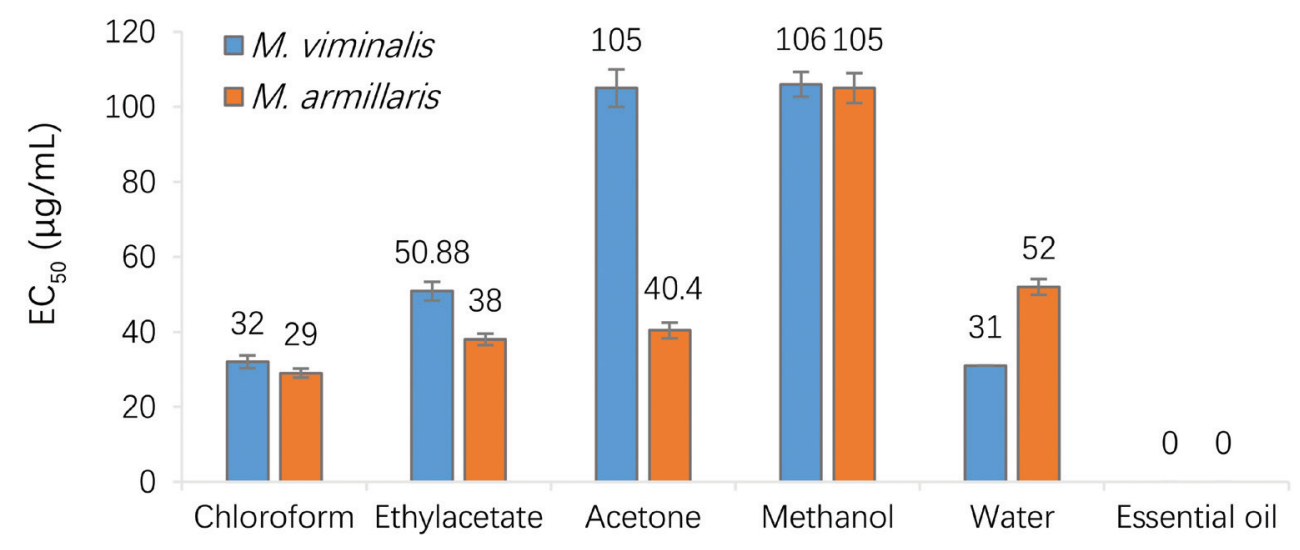

Fig. 3. FRAP of extracts and essential oils of $M$. viminalis and $M$. armillaris. 
Table 2. Antibacterial activity of extracts and essential oil of $M$. viminalis

\begin{tabular}{llllll}
\hline No. & Sample, $\mathbf{2 0} \mu \mathrm{g} / \boldsymbol{\mu L}$ & B.subtilis & A.denitrificans & K.pneumonie & S.aureus \\
\hline 1 & Ampicillin & $22 \pm 4.7 \mathrm{~mm}$ & $19.5 \pm 3.7 \mathrm{~mm}$ & $24.5 \pm 4.3 \mathrm{~mm}$ & $27.5 \pm 2.57 \mathrm{~mm}$ \\
2 & Essential oil & $22 \pm 2.73 \mathrm{~mm}$ & $18 \pm 4.7 \mathrm{~mm}$ & $15 \pm 0.97 \mathrm{~mm}$ & $23 \pm 2.56 \mathrm{~mm}$ \\
3 & Chloroform extract & $14 \pm 0.75 \mathrm{~mm}$ & $10 \pm 1.75 \mathrm{~mm}$ & $12 \pm 0.97 \mathrm{~mm}$ & $15 \pm 1.27 \mathrm{~mm}$ \\
4 & Ethylacetate extract & $16 \pm 0.67 \mathrm{~mm}$ & $13 \pm 1.17 \mathrm{~mm}$ & $10 \pm 2.47 \mathrm{~mm}$ & - \\
5 & Acetone extract & $20 \pm 1.27 \mathrm{~mm}$ & $7 \pm 0.26 \mathrm{~mm}$ & - & $12 \pm 1.87 \mathrm{~mm}$ \\
6 & Methanol extract & $17 \pm 0.75 \mathrm{~mm}$ & $11 \pm 0.57 \mathrm{~mm}$ & - & $6 \pm 1.17 \mathrm{~mm}$ \\
7 & Aqueous extract & - & - & - & - \\
\hline
\end{tabular}

Table 3. Antibacterial activity of extracts and essential oil of $M$. armillaris

\begin{tabular}{llllc}
\hline No. & Sample, $\mu \mathrm{g} / \mu \mathrm{L}$ & B. subtilis & A. denitrificans & K. pneumoniae \\
\hline 1 & Ampicillin & $15 \pm 2.37 \mathrm{~mm}$ & $18 \pm 3.3 \mathrm{~mm}$ & $20 \pm 1.27 \mathrm{~mm}$ \\
2 & Essential oil & $12 \pm 2.07 \mathrm{~mm}$ & $16 \pm 0.14 \mathrm{~mm}$ & $13 \pm 2.17 \mathrm{~mm}$ \\
3 & Chloroform extract & $9 \pm 0.87 \mathrm{~mm}$ & $8 \pm 07 \mathrm{~mm}$ & $19 \pm 1.34 \mathrm{~mm}$ \\
4 & Ethylacetate extract & $6 \pm 0.65 \mathrm{~mm}$ & $12 \pm 2.7 \mathrm{~mm}$ & $-1.12 \mathrm{~mm}$ \\
5 & Acetone extract & - & $5 \pm 3.01 \mathrm{~mm}$ & $8 \pm 0.32 \mathrm{~mm}$ \\
6 & Methanol extract & $10 \pm 1.5 \mathrm{~mm}$ & $6 \pm 3.01 \mathrm{~mm}$ & $7 \pm 0.11 \mathrm{~mm}$ \\
7 & Aqueous extract & - & - & - \\
\hline
\end{tabular}

well known for their pharmaceutical properties ${ }^{28}$; therefore, in this study, we compared the chemical constituents and biological properties of M. viminalis and M. armillaris. The chemical constituents varied between the species. Ethyl acetate, acetone and methanol extracts of $M$. viminalis and $M$. armillaris demonstrated the strong presence of terpenoids and various other secondary metabolites, such as phenolics, glycosides, flavanoids, saponins, tannins and cardiac glycosides. The major difference in essential oil composition between two species revealed thatthe major compound of $M$. viminalisis eucalyptol (74.61\%), while methyl eugenol (94.24\%) was the major compound of $M$. armillaris.

Also as mentioned earlier, eucalyptol is known to possess antibacterial properties. ${ }^{29,30}$ Although methyl eugenol (methyl ether of eugenol) is present as the major constituent in M. armillaris essential oil, this compound has been listed by the "National Toxicology Program's Report on Carcinogens' as a human carcinogen. ${ }^{31,32}$ It is well known that the variations in essential oil content and chemical composition are influenced by many factors, including location, age of the plant, climate, cultivar, method of distillation, type of distillation apparatus employed, etc. ${ }^{33,34}$ These parameters may represent factors influencing the chemical variation in both the species.

Evaluation of activities against various in vitro biological parameters indicated that the methanol extract, acetone extract and essential oil of $M$. viminalis possess the highest scavenging activities, followed by the chloroform and ethyl acetate extracts;

\section{In vitro cytotxicity of essential oils of $M$. viminalis and $M$. armillaris against human cancer cell lines}

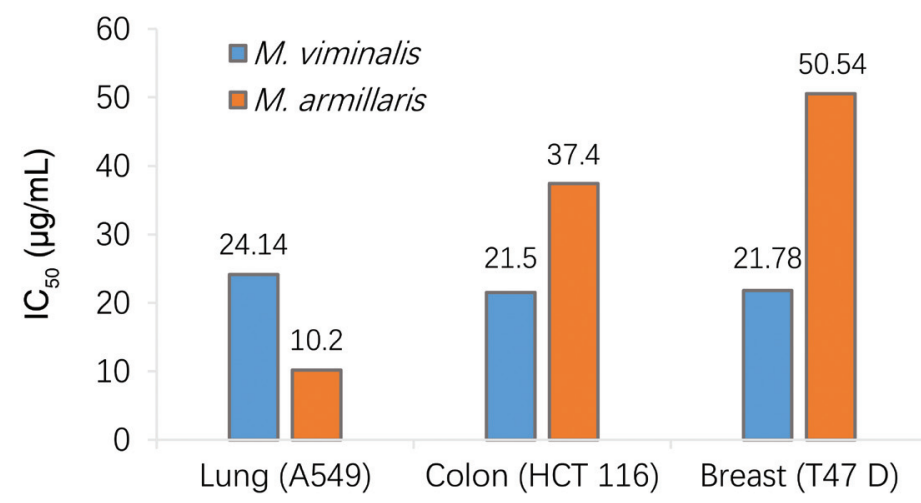

Fig. 4. In vitro cytotoxic activity of essential oils of $M$. viminalis and $M$. armillaris. 
whereas, the aqueous extract had the least activity. The ferrous chelating assay indicated that extracts of $M$. armillaris have good ferrous chelation activity, as compared to extracts of $M$. viminalis; meanwhile, the essential oil of $M$. viminalis showed more chelation power than the $M$. armillaris essential oil. Hence, the antioxidant activity in both $M$. viminalis and M. armillaris was found in accordance with Zubair et al, ${ }^{3}$ Salem et al ${ }^{35}$ and Chabir et al. ${ }^{9}$

The antibacterial activity of essential oils and extracts of both $M$. viminalis and $M$. armillaris plants were evaluated and found to be effective against the tested bacteria. The highest antimicrobial activity was observed on Gram-positive bacteria. An important characteristic of essential oils and their components is their hydrophobicity, which enables them to partition the lipids of the bacterial cell wall and disturb the cell structures thereby, rendering them more permeable. ${ }^{36,37}$ Extensive leakage from bacterial cells or the exit of critical molecules and ions will lead to death. ${ }^{38}$ Grampositive bacteria were more resistant to the essential oils than Gram-negative bacteria. ${ }^{39}$ Hence, in the present study, M. viminalis and $M$. armillaris were found to be equally effective against both Gram-positive and Gram-negative organisms.

Cytotoxicity of $M$. viminalis and $M$. armillaris was evaluated by MTT assay, a simple and reliable experimental method which measures cell viability and cytotoxicity and is used for screening cytotoxic agents. ${ }^{40}$ Findings of this experiment demonstrated that $M$. viminalis and $M$. armillaris essential oils were strongly effective against all the cell lines tested in a dose-dependent manner and were more effective against human lung (A549) cancer cells, with an $\mathrm{IC}_{50}$ value of $10.2 \mu \mathrm{g} / \mathrm{mL}$. A previous study reported the cytotoxic activity of the essential oils from the flowers and leaves of Callistemon citrinus and the presence of highly active phytochemicals, like 1,8-cineole, and monoterpenoids. ${ }^{41}$ Perhaps the cytotoxicity of $M$. viminalis and $M$. armillaris essential oils may also be attributed to the presence of phyto-constituents as well as their synergistic activities.

\section{Future research direction}

Despite promising results demonstrated by both $M$. viminalis and $M$. armillaris species against various in vitro biological parameters, there are problems that still need to be addressed, such as stability, selectivity and bioavailability of these essential oils in the human body, and for any possible adverse herb-drug interaction. Additionally, the optimal ratio and dosing regimens should be explored for higher efficacy and decreased toxicity. Thus, the future research direction would be focused on establishing these critical parameters in order to provide sufficient evidence to support going through the phases of clinical trials.

\section{Conclusions}

The present study concludes that due to the presence of phytochemicals, like eucalyptol and monoterpenoids, in the essential oils of $M$. viminalis leaves, this plant (particularly its leaves) may serve as potent source of natural anti-cancer compound(s) and should be considered for clinical trials. However, the high content of methyl eugenol, a carcinogenic compound, from $M$. armillaris (the aerial part) may raise concern, which needs to be addressed by detailed analysis, including in vivo studies and mechanistic analyses for further consideration of its potential as a human therapeutic.

\section{Acknowledgments}

The authors would like to acknowledge the DBT for the thesis grant of the students involved in this study, and the UGC-SAP, DST-FIST and Department of Bio-informatics of the University of Jammu for providing facilities and support. The authors also wish to acknowledge Prof. and Head, Dr. Yashpal Sharma, Department of Botany of the University of Jammu for help with collection and identification of the plants used in this study.

\section{Conflict of interest}

The authors have no conflicts of interest regarding this paper.

\section{Author contributions}

Study design (MB), critical revision and critical funding (MB), performance of experiments (SP, V, SG), manuscript writing (MS), analysis of data and statistical analysis (MS), administrative support (KB).

\section{References}

[1] Stefanello MÉ, Pascoal AC, Salvador MJ. Essential oils from neotropical Myrtaceae: chemical diversity and biological properties. Chem Biodivers 2011;8(1):73-94. doi:10.1002/cbdv.201000098.

[2] Chopra RN, Nayar SL, Chopra IC, Asolkar LV, Kakkar KK, Chakre OJ, et al. Glossary of Indian Medicinal Plants, 4th ed. New Delhi: Council of Scientific \& Industrial Research, 1956.

[3] Zubair M, Hassan S, Rizwan K, Rasool N, Riaz M, Zia-Ul-Haq M, et al. Antioxidant potential and oil composition of Callistemon viminalis leaves. ScientificWorldJournal 2013;2013:489071. doi:10.1155/ 2013/489071.

[4] Carson CF, Hammer KA, Riley TV. Melaleucaalternifolia (tea tree) oil: a review of antimicrobial and other medicinal properties. Clin Microbiol Rev 2006;19(1):50-62. doi:10.1128/CMR.19.1.50-62.2006.

[5] Silva CJ, Barbosa LCA, Demuner AJ, Montanari RM, Pinheiro AL, Dias I, et al. Chemical composition and antibacterial activities from the essential oils of myrtaceae species planted in Brazil. Química Nova 2010;33(1):104-108. doi:10.1590/s0100-40422010000100019.

[6] Akhtar MS, Iqbal Z, Khan MN, Lateef M. Anthelmintic activity of medicinal plants with particular reference to their use in animals in the Indo-Pakistar subcontinuent. Small Ruminant Res 2000;38:99-107.

[7] Adonizio AL, Downum K, Bennett BC, Mathee K. Anti-quorum sensing activity of medicinal plants in southern Florida. J Enthopharm 2006;105(3):427-435. doi:10.1016/j.jep.2005.11.025.

[8] Hayouni EA, Bouix M, Abedrabba M, Leveau JY, Hamdi M. Mechanism of action of Melaleuca armillaris (Sol. Ex Gaertu) Sm. essential oil on six LAB strains as assessed by multiparametric flow cytometry and automated microtiter-based assay. Food Chem 2008;111(3):707718. doi:10.1016/j.foodchem.2008.04.044.

[9] Chabir N, Romdhane M, Valentin A, Moukarzel B, Marzoug HN, Brahim NB, et al. Chemical study and antimalarial, antioxidant, and anticancer activities of Melaleuca armillaris (Sol Ex Gateau) Sm essential oil. J Med Food 2011;14(11):1383-1388. doi:10.1089/jmf.2010.0168.

[10] Farag RS, Shalaby AS, El-Baroty GA, Ibrahim NA, Ali MA, Hassan EM Chemical and biological evaluation of the essential oils of different Melaleuca species. Phytother Res 2004;18(1):30-35. doi:10.1002/ ptr.1348.

[11] Silva CJ, Barbosa LC, Maltha CR, Pinheiro AL, Ismail FM. Comparative study of the essential oils of seven Melaleuca (Myrtaceae) species grown in Brazil. Flavour Frag J 2007;22:474-478. doi:10.1002/ ffj.1823.

[12] Keszei A, Brubaker CL, Foley WJ. A molecular perspective on terpene variation in Australian Myrtaceae. Aust J of Bot 2008;56(3):197-213. 
doi:10.1071/BT07146.

[13] Barbosa LCA, Silva CJ, Teixeira RR, Meira RMSA, Pinheiro AL. Chemistry and biological activities of essential oils from Melaleuca L. Species. Agri Conspect Scient 2013;78(1):11-23.

[14] Amri I, Mancini E, De Martino L, Marandino A, Lamia H, Mohsen H, et al. Chemical composition and biological activities of the essential oils from three Melaleuca species grown in Tunisia. Int J Mol Sci 2012;13(12):16580-16591. doi:10.3390/ijms131216580.

[15] Bhagat M, Gupta S, Jamwal VS, Sharma S, Kattal M, Dawa S, et al. Comparative study on chemical profiling and antimicrobial properties of essential oils from different parts of Eucalyptus lanceolatus. Indian J Tradit Knowl 2016;15(3):425-432.

[16] Wani IA, Sogi DS, Gill BS. Physicochemical properties of acetylated starches from some Indian kidney bean (Phaseolus vulgaris L.) cultivars. Int J Food Sci \& Tech 2012;47:1993-1999. doi:10.1111/j.13652621.2012.03062.x.

[17] Chang ST, Wu JH, Wang SY, Kang PL, Yang NS, Shyur LF. Antioxidant activity of extracts from Acacia confuse bark and heartwood. J Agri Food Chem 2001;49(7):3420-3424. doi:10.1021/jf0100907.

[18] Jia ZS, Tang MC, Wu JM. The determination of flavonoid contents in mulberry and their scavenging effects on superoxide radicals. J Food Chem 1999;64(4):555-559. doi:10.1016/S0308-8146(98)00102-2.

[19] Blois MS. Antioxidant determinations by the use of a stable free radical. Nature 1958;181:1199-1200. doi:10.1038/1811199a0.

[20] Benzie IFF, Strain JJ. The ferric reducing ability of plasma (FRAP) as a measure of "antioxidant power": The FRAP assay. Anal Biochem 1996;239(1):70-76. doi:10.1006/abio.1996.0292.

[21] National Committee for Clinical Laboratory Standards. Performance standards for antimicrobial disk susceptibility test. Approved standard M2-A6. Wayne, Pa: National Committee for Clinical Laboratory Standards; 1997.

[22] Mosmann T. Rapid colorimetric assay for cellular growth and survival: Application to proliferation and cytotoxicity assays. J Immunol Methods 1983;65(1-2):55-63. doi:10.1016/0022-1759(83)90303-4.

[23] Loizzo MR, Tundis R, Menichini F, Saab AM, Statti GA, Menichini F. Cytotoxic activity of essential oils from labiatae and lauraceae families against in vitro human tumor models. Anticancer Res 2007;27(5A):3293-3300.

[24] Jones FA. Herbs-useful plants. Their role in history and today. Eur J Gastroenterol Hepatol 1996;8(12):1227-1231.

[25] Reynolds JEF. Martindale: the Extra Pharmacopoeia. 31st ed. London: Pharmaceutical Press, 1996.

[26] Lis-Balchin M, Deans SG. Bioactivity of selected plant essential oils against Listeria monocytogenes. J Appl Microbiol 1997;82(6):759762. doi:10.1046/j.1365-2672.1997.00153.x

[27] Carson CF, Hammer KA, Riley TV. Melaleucaalternifolia (Tea Tree) oil: a review of antimicrobial and other medicinal properties. Clin Microbiol Rev 2006;19(1):50-62. doi:10.1128/CMR.19.1.50-62.2006.

[28] Cascaes MM, Guilhon GMSP, Andrade EHA, Zoghbi MGB, Santos LS. Constituents and pharmacological activities of Myrcia (Myrtaceae): A review of an aromatic and medicinal group of plants. Int J Mol Sci 2015;16(10):23881-23904. doi:10.3390/ijms161023881.
[29] Andrade-Ochoa S, Nevárez-Moorillón GV, Sánchez-Torres LE, Villanueva-García M, Sánchez-Ramírez BE, Rodríguez-Valdez LM, et al. Quantitative structure-activity relationship of molecules constituent of different essential oils with antimycobacterial activity against $M y$ cobacterium tuberculosis and Mycobacterium bovis. BMC Complement Altern Med 2015;15:332. doi:10.1186/s12906-015-0858-2.

[30] Yang SJ, Han SH, Lee AR, Jun JH, Son MW, Oh SH, et al. Evaluation of antimicrobial effects of commercial mouthwashes utilized in South Korea. BMB Rep 2015;48(1):42-47. doi:10.5483/BMBRep.2015.48.1.090.

[31] Sipe HJ, Lardinois OM, Mason RP. Free radical metabolism of methyleugenol and related compounds. Chem Res Toxicol 2014;27(4):483489. doi:10.1021/tx400256b.

[32] Johnson JD, Ryan MJ, Toft JD, Graves SW, Hejtmancik MR, Cunningham ML, et al. Two-year toxicity and carcinogenicity study of methyleugenol in $\mathrm{F} 344 / \mathrm{N}$ rats and $\mathrm{B} 6 \mathrm{C} 3 \mathrm{~F}(1)$ mice. J Agric Food Chem 2000;48(8):3620-3632. doi:10.1021/jf000364a.

[33] Babu KGD, Kaul VK. Variation in essential oil composition of rosescented geranium (Pelargonium sp.) distilled by different distillation techniques. Flavour Fragr J 2005;20:222-231. doi:10.1002/ffj.1414.

[34] Babu KGD, Kaul VK. Variations in quantitative and qualitative characteristics of wild marigold (Tagetes minuta L.) oils distilled under vacuum and at NTP. Ind Crops Prod 2007;26:241-251. doi:10.1016/j. indcrop.2007.03.013.

[35] Salem MZ, Ali HM, El-Shanhorey NA, Abdel-Megeed A. Evaluation of extracts and essential oil from Callistemon viminalis leaves: antibacterial and antioxidant activities, total phenolic and flavonoid contents. Asian Pac J Trop Med 2013;6(10):785-791. doi:10.1016/ S1995-7645(13)60139-X.

[36] Knobloch K, Weigand H, Weis N, Schwarm H-M, Vigenschow H. Action of terpenoids on energy metabolism. In: Brunke EJ, editor. Progress in Essential Oil Research: 16th International Symposium on Essential Oils. Berlin: De Gruyter; 1986. p429-445.

[37] Sikkema J, De Bont JAM, Poolman B. Interactions of cyclic hydrocarbons with biological membranes. J Biol Chem 1994;269(11):80228028.

[38] Denyer SP, Hugo WB. Biocide-induced damage to the bacterial cytoplasmic membrane. In: Denyer SP, Hugo WB, editors. Mechanisms of Action of Chemical Biocides. The Society for Applied Bacteriology, Technical Series No 27. Oxford: Oxford Blackwell Scientific Publication; 1991. p171-188.

[39] Zaika LL. Spices and herbs: their antibacterial activity and its determination. J Food Saf 1988;23:97-118. doi:10.1111/j.1745-4565.1988. tb00511.x.

[40] Rietjens IM, Martena MJ, Boersma MG, Spiegelenberg W, Alink GM. Molecular mechanisms of toxicity of important food-borne phytotoxins. Mol Nutr Food Res 2005;49(2):131-158. doi:10.1002/ mnfr.200400078.

[41] Kumar D, Sukapaka M, Babu GD, Padwad Y. Chemical composition and in vitro cytotoxicity of essential oils from leaves and flowers of callistemon citrinus from Western Himalayas. PLoS One 2015;10(8):e0133823. doi:10.1371/journal.pone.0133823. 